\title{
Obowiązek przeprowadzenia przez organ administracji publicznej konfrontacji biegłych w przypadku istotnych rozbieżności pomiędzy ich opiniami
}

\author{
Wyrok Naczelnego Sądu Administracyjnego z dnia 17 października 2019 r., \\ II OSK 1217/19
}

W sytuacji gdy niezbędne jest przeprowadzenie dowodu z opinii biegłego, zaś opinie biegłych poddane ocenie organów mają diametralnie różne konkluzje, obowiązkiem organów jest skonfrontowanie biegłych będących autorami tych opinii, przy jednoczesnym zapewnieniu stronom możliwości zadawania pytań - stosownie do dyspozycji art. $10 \mathrm{w}$ zw. $z$ art. 79 § 1 i 2 k.p.a. W tym celu konieczne wydaje się przeprowadzenie rozprawy administracyjnej.

\author{
Adam Bochentyn \\ Uniwersytet Gdański \\ adam.bochentyn@prawo.ug.edu.pl \\ ORCID: 0000-0002-8234-1786
}

https://doi.org/10.26881/gsp.2020.2.10

\section{Glosa}

Glosowane orzeczenie ${ }^{1}$ i sformułowana w nim teza odnoszą się do konfrontacji biegłych - zagadnienia o dużym znaczeniu praktycznym, niezwykle istotnego dla przebiegu i wyniku postępowania administracyjnego. Wartość poglądu przyjętego przez Naczelny Sąd Administracyjny (NSA) nie wyraża się w jego kontrowersyjności czy też w przełamaniu lub utrwaleniu określonej linii orzeczniczej, lecz w tym, że dotyczy on instytucji, która - jeżeli chodzi o ogólne postępowanie administracyjne - nie została przez ustawodawcę w ogóle uregulowana. Wiąże się to z ogólną cechą polskiego kodeksu postępowania administracyjnego ${ }^{2}$, charakteryzującą akt ten od momentu jego uchwalenia 60 lat temu. Już $w$ tekście pierwotnym ${ }^{3}$ kodeks charakteryzował

\footnotetext{
1 Wyrok NSA z dnia 17 października 2019 r., II OSK 1217/19, LEX nr 2759117.

2 Ustawa z dnia 14 czerwca 1960 r. - Kodeks postępowania administracyjnego (tekst jedn.: Dz. U. z 2020 r., poz. 256; dalej: k.p.a.).

3 Zob. Dz. U. z 1960 r. Nr 30, poz. 168.
} 
się znaczną lakonicznością, widoczną szczególnie w porównaniu z przyjętymi w tym samym okresie ustawami regulującymi postępowanie cywilne ${ }^{4}$ i karne ${ }^{5}$. Lapidarność k.p.a. jest szczególnie zauważalna w zakresie przepisów regulujących postępowanie dowodowe, w tym udział biegłego w postępowaniu administracyjnym ${ }^{6}$. Zatem tym bardziej należy się pochylić nad wyrokiem NSA z dnia 17 października 2019 r.

Glosowane orzeczenie NSA zapadło w następującym stanie faktycznym. Decyzją z czerwca 2018 r., Samorządowe Kolegium Odwoławcze w L. uchyliło w całości decyzję wójta gminy K. z kwietnia 2018 r. oraz nakazało Generalnej Dyrekcji Dróg i Autostrad (GDDKiA) oddział w W. wykonanie w terminie do listopada 2018 r. odwodnienia liniowego na zjeździe z kostki brukowej w bezpośrednim sąsiedztwie z bramą zjazdową i na północ od niej oraz na linii korytek z profili betonowych biegnących wzdłuż północnego jej ogrodzenia. W toku postępowania poprzedzającego wydanie wskazanych decyzji pięciokrotnie orzekały w sprawie organy obu instancji, a Wojewódzki Sąd Administracyjny (WSA) w Lublinie wydał cztery wyroki ${ }^{7}$. W toku postępowania, na przestrzeni kilku lat, zebrano materiał dowodowy, w skład którego wchodziło m.in. osiem opinii biegłych. Część z tych opinii została sporządzona na zlecenie organu prowadzącego postępowanie administracyjne lub na zlecenie GDDKiA, ale w toku tego postępowania, jak również w toku prowadzonego równolegle postępowania przed Sądem Okręgowym I Wydział Cywilny w L. opinie te zostały przez organ pierwszej instancji (wójta gminy K.) włączone do materiału rozpoznawanej sprawy. W wyroku z dnia 23 maja 2017 r. WSA w Lublinie wskazał na błąd organów, polegający na pominięciu niektórych (sporządzonych na wcześniejszym etapie postępowania) opinii biegłych oraz na konieczność poddania ich ocenie. Z uwagi na diametralnie różne wnioski formułowane w opiniach, WSA zaakcentował konieczność dokonania konfrontacji biegłych będących autorami tych opinii. Z uwagi na potrzebę zapewnienia udziału stron w tej konfrontacji, sąd uznał za konieczne przeprowadzenie rozprawy administracyjnej.

4 Ustawa z dnia 17 listopada 1964 r. - Kodeks postępowania cywilnego (Dz. U. Nr 43, poz. 296).

5 Ustawa z dnia 19 kwietnia 1969 r. - Kodeks postępowania karnego (Dz. U. Nr 13, poz. 96). Kodeks postępowania karnego z 1969 r. został uchylony przez art. 3 § 1 ustawy z dnia 6 czerwca 1997 r. - Przepisy wprowadzające Kodeks postępowania karnego (Dz. U. Nr 89, poz. 556, ze zm.).

6 W tekście pierwotnym k.p.a. dowodom poświęcone były przepisy art. 70-81 (obecnie są to art. 75-88a), natomiast dowód z opinii biegłego był regulowany przez art. 78 (obecnie art. 84). Z kolei w kodeksie postępowania cywilnego, zarówno w jego tekście pierwotnym, jak i obecnie obowiązującym (tekst jedn.: Dz. U. z 2019 r., poz. 1460, ze zm.; dalej: k.p.c.), dowodom poświęcone zostały przepisy art. 227-315, w tym art. 278-289 dotyczące biegłego i jego opinii. Natomiast w kodeksie postępowania karnego z 1969 r. dowody były uregulowane w przepisach art. 152-204, z czego do opinii biegłego odnosiły się przepisy art. 176-184. Lakoniczność k.p.a. jest jeszcze bardziej widoczna w zestawieniu z obecnie obowiązującą ustawą z dnia 6 czerwca 1997 r. - Kodeks postępowania karnego (tekst jedn.: Dz. U. z 2020 r., poz. 30, ze zm.; dalej: k.p.k.), w której dowodom poświęcono przepisy art. 167-242 (dowodu z opinii biegłego dotyczą przepisy art. 193-203).

7 Wyroki WSA w Lublinie z dnia: 3 kwietnia 2012 r., II SA/Lu 45/12, LEX nr 2878986; 3 grudnia 2013 r., II SA/Lu 351/13, LEX nr 1407083; 13 sierpnia 2015 r., II SA/Lu 1089/14, LEX nr 2835139 oraz 23 maja 2017 r., II SA/Lu 1134/16, LEX nr 2342075.

8 Zwrócić należy uwagę, że wyrok WSA w Lublinie z dnia 23 maja 2017 r., II SA/Lu 1134/16, jako orzeczenie prawomocne, jest wiążący, zgodnie z treścią przepisu art. 170 ustawy z dnia 30 sierpnia 2002 r. - Prawo o postępowaniu przed sądami administracyjnymi (tekst jedn.: Dz. U. z 2019 r., 
W skardze do sądu administracyjnego na decyzję z czerwca 2018 r. skarżąca zarzuciła organom naruszenie przepisów postępowania, które miało istotny wpływ na wynik sprawy, a mianowicie art. 7 k.p.a., art. $77 \S 1$ k.p.a., art. 80 k.p.a., art. $107 \S 3$ k.p.a. W wyroku ${ }^{9}$ z dnia 4 grudnia 2018 r., WSA w Lublinie orzekł o oddaleniu skargi. W jego ocenie organ pierwszej instancji podjął właściwe kroki w zakresie konfrontacji biegłych, w tym przeprowadził dwie rozprawy administracyjne, na które wezwani zostali wszyscy biegli. Stanowisko WSA w Lublinie podzielił NSA i glosowanym wyrokiem oddalił skargę kasacyjną.

Stanowisko NSA przedstawione w komentowanym orzeczeniu, odnoszące się do obowiązku przeprowadzenia przez organ prowadzący postępowanie administracyjne konfrontacji biegłych w przypadku istotnych rozbieżności pomiędzy ich opiniami, zasługuje na aprobatę. Zastrzec należy jednak, że o ile w stanie faktycznym, w którym zapadło orzeczenie, konfrontacja była konieczna, o tyle nie zawsze rozbieżność pomiędzy opiniami biegłych będzie jednoznaczna z obowiązkiem skonfrontowania biegłych. Podobnie podzielić należy pogląd sądu o konieczności przeprowadzenia rozprawy w celu dokonania konfrontacji oraz zapewnienia stronie udziału w przeprowadzonej czynności. W tym miejscu poczynić należy jednak pewną uwagę natury ogólnej, odnoszącą się do samego charakteru biegłego oraz jego opinii. Za biegłego w rozumieniu art. 84 k.p.a. może zostać uznana jedynie osoba, która została powołana w tym charakterze przez organ administracji publicznej i tylko opinia takiej osoby stanowi dowód z opinii biegłego w świetle wskazanego przepisu. Natomiast nie wszystkie opinie, do których odnosił się NSA w komentowanym orzeczeniu, powstały na zlecenie organu administracji publicznej. Nie zmienia to jednak faktu, że możliwe jest, jak to przyjął sąd, skonfrontowanie ze sobą autorów wszystkich opinii przygotowanych w sprawie.

Konfrontacja stanowi specyficzną formę przesłuchania biegłych, polegającą na bezpośrednim i jednoczesnym przesłuchiwaniu co najmniej dwóch biegłych na tę samą okoliczność, w celu wyjaśnienia sprzeczności pomiędzy wydanymi przez nich

poz. 2325 , ze zm.), nie tylko dla strony i sądu, który go wydał, lecz również dla innych sądów i innych organów państwowych, a w przypadkach przewidzianych w ustawie - także dla innych osób. Naczelny Sąd Administracyjny, wydając komentowane orzeczenie, podobnie jak sąd orzekający w pierwszej instancji, nie mógł zatem abstrahować od sformułowanych we wskazanym wyroku wskazań co do dalszego postępowania. Obowiązkiem sądów obu instancji było odniesienie się do tego, czy organy administracji publicznej prawidłowo wykonały te wskazania, gdyż były one dla nich wiążące, na co wprost wskazuje przepis art. 153 prawa o postępowaniu przed sądami administracyjnymi. Nie zmienia to jednak faktu, że oceniając zgodność z prawem „nowych” decyzji, wydanych na podstawie wskazań sformułowanych w wyroku WSA w Lublinie z dnia 23 maja 2017 r., sądy administracyjne, pierwszej i drugiej instancji, mogły formułować własne oceny co do tego, jakie działania powinien podjąć organ w przypadku dysponowania kilkoma opiniami biegłych o diametralnie różnych konkluzjach. W związku z tym teza przyjęta przez NSA w glosowanym orzeczeniu pomimo tego, że jest zbieżna z poglądem wyrażonym przez WSA w Lublinie w wyroku z dnia 23 maja 2017 r., nie może być traktowana jedynie jako jego mechaniczne powtórzenie. Zbieżność ta ma jednak to znaczenie, że sformułowane w glosie uwagi dotyczące tezy komentowanego orzeczenia NSA można również odnieść do poglądu wyartykułowanego przez WSA w Lublinie w wyroku z dnia 23 maja 2017 r., II SA/Lu 1134/16.

9 Wyrok WSA w Lublinie z dnia 4 grudnia 2018 r., II SA/Lu 715/18, LEX nr 2629070. 
uprzednio opiniami ${ }^{10}$. Do konfrontacji powinno dochodzić, jak zauważyła Justyna Żylińska, wówczas „gdy ocenie organu poddane zostały dwie (lub więcej) opinie, z których każda analizowana oddzielnie ma, według oceny organu procesowego, przymiot jasności, zupełności i jest logiczna, a mimo to zachodzi rozbieżność między istotnymi elementami porównywanych opinii. Organowi w tej sytuacji trudno jest sprecyzować istotę sprzeczności"11. Konfrontację uznaje się, zależnie od sytuacji dowodowej, za optymalne narzędzie służące wyjaśnieniu zaistniałych sprzeczności, a tym samym dokonaniu prawidłowych ustaleń faktycznych ${ }^{12}$. Na niezwykle ważne jej aspekty zwrócili uwagę Grzegorz Kopczyński i Łukasz Cora. Pierwszy z Autorów wskazał, że jednym z celów konfrontacji jest „umożliwienie stronom na zasadzie kontradyktoryjności kontroli dowodu z opinii biegłych"13. Łukasz Cora podkreślił z kolei, że celowość jej przeprowadzenia „jest szczególnie uzasadniona w dowodowo złożonych i skomplikowanych sprawach"14.

Zalety konfrontacji biegłych trafnie wyeksponował Tadeusz Tomaszewski. W jego ocenie, po pierwsze, może ona „doprowadzić do uzgodnienia stanowisk biegłych czy nawet uznania przez jednego z nich racji drugiego eksperta, co na ogół jest możliwe tylko w wyniku ich osobistego kontaktu. Praktyka dowodzi jednak, że biegli nie zawsze mogą lub potrafią uzgodnić swoje poglądy albo nawet przyznać się do błędu w opiniowaniu". Po drugie, przy uzasadnionym podtrzymaniu przez biegłych swoich stanowisk konfrontacja może „umożliwić organowi procesowemu - w ramach swobodnej oceny dowodów, przez porównanie użytych argumentów i stopnia kategoryczności prezentowanych w przesłuchaniu wniosków - określenie wiarygodności każdej z opinii. Konfrontacja zatem może pozwolić na wyeliminowanie konieczności powołania nowego biegłego w celu przeprowadzenia ponownej ekspertyzy"15. Wymienione zalety występują niezależnie od tego, w jakim postępowaniu - sądowym czy administracyjnym, instytucja ta jest wykorzystywana.

Możliwość prowadzenia konfrontacji przewidują expressis verbis przepisy kodeksu postępowania karnego oraz kodeksu postępowania cywilnego. Zgodnie z treścią art. 172 k.p.k.: „Osoby przesłuchiwane mogą być konfrontowane w celu wyjaśnienia sprzeczności. Konfrontacja nie jest dopuszczalna w wypadku określonym w art. 184".

10 G. Kopczyński, Konfrontacja biegłych w polskim procesie karnym, Warszawa 2008, s. 107-108. W doktrynie postępowania karnego przyjmuje się przeważnie, że w konfrontacji, co do zasady, powinny uczestniczyć jedynie dwie osoby. Przeprowadzenie konfrontacji grupowej dopuszcza się jednak w przypadku konfrontowania biegłych; por. D. Jagiełło, Glosa do wyroku s.apel. z dnia 3 października 2012 r., Il AKa 260/12, Ilus Novum" 2013, nr 4, s. 152. Podkreśla się, że jest to spowodowane potrzebami praktyki, ponieważ niejednokrotnie powołuje się trzech lub więcej biegłych, których opinie są ze sobą sprzeczne; zob. T. Tomaszewski, Dowód z opinii biegłego w procesie karnym, Kraków 2000, s. 97.

11 J. Żylińska, Przesłanki konfrontacji, Prok. i Pr. 2013, nr 2, s. 157.

12 D. Orkiszewska, Glosa do postanowienia SN z dnia 20 sierpnia 2014 r., II KK 204/14, Prok. i Pr. 2016, nr 2, s. 187.

13 G. Kopczyński, Konfrontacja biegłych..., s. 113-114.

14 Ł. Cora, Charakter prawny czynności kontrolujących dowody, "Przegląd Sądowy" 2018, nr 11-12, s. 76.

15 T. Tomaszewski, Dowód z opinii..., s. 95. 
Abstrahując od treści art. 184 k.p.k., który odnosi się do świadków anonimowych, zaznaczyć należy, że do kategorii osób przesłuchiwanych należą także powołani w sprawie biegli ${ }^{16}$. Natomiast w postępowaniu cywilnym przepis art. 272 k.p.c. wskazuje: „Świadkowie, których zeznania przeczą sobie wzajemnie, mogą być konfrontowani”. Przepis ten wprawdzie nie odnosi się wprost do biegłych, jednakże sąd może na jego podstawie przeprowadzić konfrontację pomiędzy biegłymi, których opinie „przeczą sobie wzajemnie”, ze względu na odesłanie zawarte w art. 289 k.p.c. („Do wezwania i przesłuchania biegłych stosuje się ponadto odpowiednio przepisy o świadkach, z wyjątkiem przepisów o przymusowym sprowadzeniu").

Jak zauważyła J. Żylińska, pomimo tego, że „konfrontacja stanowi szczególną formę przesłuchania, ustawodawca nadał jej odpowiednią rangę przez uregulowanie w odrębnej podstawie prawnej - art. 172 k.p.k." ${ }^{17}$. Podobnie polski prawodawca uczynił w odniesieniu do konfrontacji w postępowania cywilnym. Zabiegu takiego nie dokonał wprawdzie w odniesieniu do kodeksu postępowania administracyjnego, jednakże w żadnym razie nie można negować możliwości przeprowadzenia konfrontacji w ogólnym postępowaniu administracyjnym, a jej znaczenia dla wyników tego postępowania - bagatelizować.

Odnosząc się do prowadzenia konfrontacji biegłych w postępowaniu administracyjnym, w pierwszej kolejności zaznaczyć należy, że przepis art. 84 § 1. k.p.a. wyraźnie dopuszcza możliwość zwrócenia się przez organ o wydanie opinii nie tylko do jednego biegłego, lecz również do kilku biegłych (formuła: „może zwrócić się do biegłego lub biegłych o wydanie opinii"). Powołując w sprawie co najmniej dwóch biegłych, organ może zlecić im przygotowanie opinii łącznej (wspólnie) ${ }^{18}$ bądź też zlecić każdemu przygotowanie osobnej opinii, nawet jeżeli miałaby ona dotyczyć tego samego zagadnienia. W takim właśnie przypadku, jeżeli organ zleca przygotowanie odrębnych opinii kilku biegłym, a ich zakres i przedmiot przynajmniej w części są tożsame, dojść może pomiędzy nimi do rozbieżności. Różnice pomiędzy opiniami mogą być spowodowane m.in. dysponowaniem przez biegłych różnym materiałem badawczym, stosowaniem odmiennych metod badawczych, przeprowadzaniem badań w różnych warunkach, reprezentowaniem odmiennych szkół naukowych, przeprowadzaniem badań w różnym okresie od momentu zaistnienia zdarzenia, różnym zakresem dostępu do dokumentacji potrzebnej do przeprowadzenia badań, różną interpretacją uzyskanych wyników oraz różnicą w stosowanej przez biegłych terminologii ${ }^{19}$.

Przepisy kodeksu postępowania administracyjnego, pozwalając na powołanie w sprawie kilku biegłych, nie przewidują wprost instrumentów umożliwiających

\footnotetext{
16 L.K. Paprzycki [w:] Kodeks postępowania karnego, t. 1, Komentarz do art. 1-424, red. idem, Warszawa 2013, s. 586.

17 J. Żylińska, Konfrontacja biegłych jako metoda wyjaśnienia sprzeczności między różnymi opiniami w tej samej sprawie, PiP 2013, z. 10, s. 75.

18 Zdaniem Filipa Elżanowskiego, brak jest możliwości sporządzenia przez biegłych opinii łącznej, zob. idem [w:] Kodeks postępowania administracyjnego. Komentarz, red. R. Hauser, M. Wierzbowski, Warszawa 2018, s. 670.

19 J. Żylińska, Konfrontacja biegłych..., s. 76.
} 
wyjaśnienie rozbieżności pomiędzy ich opiniami. Nie oznacza to jednak, że nie dają żadnej podstawy do rozwiązania wskazanej sytuacji. Po pierwsze, przepisy k.p.a. przewidują możliwość przesłuchania biegłego (art. 67 § 2 pkt 2 k.p.a., art. 77 § 3 k.p.a., art. 79 § 1 i 2 k.p.a.). Nie ma żadnego powodu wynikającego z przepisów prawnych, a tym bardziej żadnych argumentów natury praktycznej, które uzasadniałyby brak możliwości przesłuchania w tym samym miejscu i czasie większej liczby biegłych. Po drugie, jedną z przesłanek przeprowadzenia rozprawy administracyjnej jest potrzeba "wyjaśnienia sprawy przy udziale świadków lub biegłych albo w drodze oględzin" (art. 89 $\S 2$ k.p.a.). Tym samym rozprawa może zostać przeprowadzona w sytuacji zaistnienia potrzeby wyjaśniania sprawy z udziałem biegłych i ich przesłuchania.

Przesłuchanie biegłych może przybrać formę konfrontacji, nawet jeżeli nie wynika ona wprost z przepisów k.p.a. Zaakcentowania wymaga, że przyjęcie takiego poglądu w żadnym stopniu nie oznacza nałożenia bez podstawy prawnej dodatkowego obowiązku na osobę powołaną w charakterze biegłego. Obowiązek przedstawienia opinii na wezwanie organu administracji publicznej wynika z art. 84 § 2 zdanie drugie k.p.a., zgodnie z którym „, do biegłych stosuje się przepisy dotyczące przesłuchania świadków", w związku z art. 83 § 1 k.p.a., który wskazuje, że nikt - oprócz wyliczonych w przepisie osób - nie ma prawa odmówić zeznań w charakterze świadka. W związku z treścią wskazanych przepisów przyjąć należy, że nikt nie ma prawa, z wyjątkiem ściśle określonych osób ${ }^{20}$, odmówić wydania opinii w charakterze biegłego, jeżeli zwraca się do niego o to organ administracji publicznej. Ponadto, osoba wezwana na przesłuchanie, którą może być również biegły, obowiązana jest do osobistego stawienia się w obrębie gminy lub miasta, w którym zamieszkuje albo przebywa (art. 51 § 1 k.p.a.) oraz w sąsiedniej gminie albo mieście (art. 51 § 2 k.p.a.). Dodatkowo, jeżeli charakter sprawy lub czynności wymaga dokonania czynności przed organem administracji publicznej prowadzącym postępowanie, to ograniczenia wskazanego $w$ art. 51 k.p.a. nie stosuje

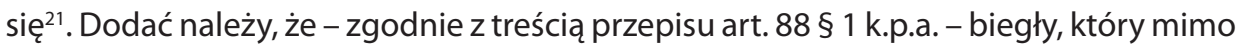
prawidłowego wezwania nie stawił się bez uzasadnionej przyczyny lub bezzasadnie odmówił wydania opinii albo udziału w innej czynności urzędowej, może być ukarany grzywną do 50 zł, a w razie ponownego niezastosowania się do wezwania - grzywną do 200 zł.

Organ administracji publicznej powinien sięgnąć po formę konfrontacji, jeżeli będzie to niezbędne do prawidłowego wyjaśnienia sprawy. Chodzi o takie sytuacje, w których nie będzie on zdolny do samodzielnego rozstrzygnięcia wątpliwości wynikłych na tle rozbieżnych opinii biegłych. Przypomnieć należy, że przepis art. 7 k.p.a.

\footnotetext{
20 Na marginesie rozważań zaznaczyć należy, że osoby, które posiadają prawo do odmowy wydania opinii, na podstawie art. 84 § 2 zdanie drugie k.p.a. w związku z art. 83 § 1 k.p.a., podlegają jednocześnie wyłączeniu od udziału w sprawie na podstawie art. 84 § 2 zdanie pierwsze k.p.a. w związku $z$ art. 24 § 1 pkt 2 i 3 k.p.a.

21 Przyjąć należy, że w przypadku konfrontacji biegłych, przeprowadzanej przez organ prowadzący postępowanie administracyjne, charakter czynności uzasadnia zastosowanie art. 53 k.p.a. Biegły będzie w takiej sytuacji zobowiązany do osobistego stawiennictwa, niezależnie od miejsca zamieszkania lub miejsca pobytu.
} 
zobowiązuje organ do podejmowania w toku postępowania wszelkich czynności niezbędnych do dokładnego wyjaśnienia stanu faktycznego oraz do załatwienia sprawy. Jeżeli wyjaśnienie rozbieżności pomiędzy opiniami biegłych wymaga skonfrontowania ze sobą autorów tych opinii, organ obowiązany jest dokonać przesłuchania biegłych w formie konfrontacji.

Do stanu faktycznego, w jakim zapadło komentowane orzeczenie NSA, odnieść można przywołany już w pracy pogląd Ł. Cory, zgodnie z którym szczególnie uzasadnione jest przeprowadzenie konfrontacji w dowodowo złożonych i skomplikowanych sprawach $^{22}$. Wprawdzie zacytowana opinia odnosi się wprost do konfrontacji w postępowaniu karnym, jednakże należy nadać jej znaczenie uniwersalne. Sprawę, w której organy administracji publicznej na określonym etapie postępowania dysponowały ośmioma różnymi opiniami biegłych, które dodatkowo miały diametralnie różne konkluzje, można niewątpliwe uznać za skomplikowaną. Świadczy o tym również fakt, że w sprawie, w której wydane zostały opinie, pięciokrotnie orzekały organy obu instancji, a czterokrotnie wypowiadał się sąd administracyjny.

Doprecyzować należy, w odniesieniu do obowiązku przeprowadzenia konfrontacji biegłych, że nie zawsze w przypadku otrzymania przez organ dwóch lub więcej sprzecznych opinii celowe będzie przeprowadzenie takiej konfrontacji. Odnosząc się do treści art. 172 k.p.k., Sąd Najwyższy (SN) stwierdził23, że przepis ten nie nakłada na sąd obowiązku przeprowadzenia konfrontacji świadków w każdym wypadku sprzeczności w ich zeznaniach, lecz jedynie w sytuacji, gdy może to się przyczynić do prawidłowego ustalenia stanu faktycznego. Podobnie, w wyroku² z 2004 r. SN przyjął, że konfrontacja osób przesłuchiwanych, wskazana w art. 172 k.p.k., nie jest czynnością obligatoryjną. Ma ona na celu, w ocenie sądu, ewentualne wyjaśnienie sprzeczności w oświadczeniach osób przesłuchiwanych, dla ustalenia wiarygodności poszczególnych osobowych źródeł dowodowych. W glosie do pierwszego ze wskazanych wyżej orzeczeń Józef Gurgul stwierdził, że „kryterium sprzeczności jako przesłanka zarządzenia konfrontacji nie jest na tyle jednoznaczne, żeby mogło działać mechanicznie. Przede wszystkim trzeba mieć na uwadze, że werbalna niezgodność zeznań (wyjaśnień, opinii biegłych) jest efektem wielu przyczyn. Na przykład, niekiedy wynika ona z pomyłki, a kiedy indziej znowu z celowego kłamstwa jednego lub obu świadków (podejrzanych, biegłych). Przeciwstawność relacji to także skutek błędnego spostrzegania, zapamiętywania lub odtwarzania, przy czym wnioski co do zachowań organu procesowego w każdym z tych przypadków rozbieżności muszą być indywidualizowane ${ }^{\prime 25}$. Trafnie przyjął SN w postanowieniu ${ }^{26}$ z 2006 r., że prowadzenie konfrontacji będzie niepotrzebne „w sytuacji, gdy jedna z opinii zostanie w sposób niebudzący zastrzeżenia zdyskwalifikowana. Sprzeczność pomiędzy opiniami biegłych uzasadniać

22 Ł. Cora, Charakter prawny..., s. 76.

23 Postanowienie SN z dnia 27 lutego 2001 r., III KKN 484/99, LEX nr 48854.

24 Wyrok z dnia 1 kwietnia 2004 r., III KK 198/03, LEX nr 109498.

25 J. Gurgul, Glosa do postanowienia SN z dnia 27 lutego 2001 r., III KKN 484/99, Prok. i Pr. 2002, nr 2, S. 121.

26 Postanowienie z dnia 3 kwietnia 2006 r., III KK 294/05, LEX nr 182990. 
może konieczność ponownego wezwania tych samych lub nowych biegłych tylko wtedy, gdy owe sprzeczności uniemożliwiają sądowi orzekającemu zajęcie stanowiska w kwestiach będących przedmiotem opinii i mających znaczenie dla rozstrzygnięcia sprawy". Wprawdzie przywołane poglądy odnosiły się do przepisów kodeksu postępowania karnego, nie ma jednak żadnych powodów, aby rozważaniom na temat celowości przeprowadzenia konfrontacji nie można było nadać znaczenia uniwersalnego, wspólnego dla różnych procedur. Podkreślenia wymaga, że w stanie faktycznym, w jakim wydane zostało komentowane orzeczenie, przeprowadzenie konfrontacji było warunkiem prawidłowej oceny opinii sporządzonych w toku sprawy.

Niezwykle interesującym wątkiem podniesionym w komentowanym orzeczeniu, wykraczającym w ocenie autora glosy poza sam problem konfrontacji biegłych, jest stosowanie w postępowaniu administracyjnym przepisów procedury karnej lub cywilnej. Jak podkreślił NSA w uzasadnieniu do wyroku:„Błędne jest tym samym stanowisko autora skargi kasacyjnej o nienależytym wykonaniu przez organ obowiązku skonfrontowania biegłych w drodze rozprawy administracyjnej. Odnosząc się zaś do argumentacji o konieczności sięgnięcia w tym zakresie do innych procedur cywilnej (art. 289 k.p.c., art. 262-265 k.p.c., art. 271-273 k.p.c.) i karnej (art. 172 k.p.k.), stwierdzić trzeba, że autor skargi kasacyjnej nie wskazał, który konkretnie przepis - jego zdaniem - zawiera odesłanie do stosowania przepisów k.p.c. i k.p.k., w trakcie rozprawy administracyjnej, powołując się ogólnie w tym zakresie na »analogię«. W szczególności trudno upatrywać takiej podstawy w sformułowanych w treści zarzutu przepisach art. 84 § 1 i art. 89 § 2 k.p.a." Odnosząc się do wskazanego fragmentu uzasadnienia orzeczenia NSA, zaznaczyć należy, że faktycznie żaden z przepisów k.p.a. nie nakłada na organ administracji publicznej obowiązku stosowania przepisów k.p.c. i k.p.k. w tych przypadkach, w których k.p.a. danej kwestii nie reguluje. Jak już w pracy zaznaczono, k.p.a. cechuje się w porównaniu z k.p.c. i k.p.k. wyraźną lapidarnością. Przepisy k.p.a., inaczej niż przepisy ustaw regulujących postępowania karne i cywilne, m.in. nie określają formy, w jakiej powinna zostać przedstawiona przez biegłego opinia oraz elementów jej treści, nie normują zagadnienia opinii uzupełniającej oraz opinii instytutu naukowego, naukowo-badawczego lub innej specjalistycznej instytucji. Nie zmienia to jednak faktu, że bez przepisu odsyłającego nie może organ administracji publicznej stosować przepisów procedury innej niż administracyjna, a strona nie może skutecznie podnosić wobec niego zarzutów niestosowania tych przepisów. Nie oznacza to jednak, że prowadząc postępowanie administracyjne, organ nie może korzystać, np. w zakresie konfrontacji biegłych, z pewnych rozwiązań przyjętych w przepisach k.p.c. lub k.p.k., w kwestiach, których przepisy k.p.a. nie regulują. Ponadto zaznaczyć należy, że niezwykle istotny jest dla prowadzenia postępowania administracyjnego dorobek judykatury i doktryny, który pozwala na skompensowanie niedoskonałości przepisów regulujących ogólne postępowanie administracyjne. Pojęciem „dorobku judykatury i doktryny" objąć należy nie tylko poglądy sądów administracyjnych i doktryny postępowania administracyjnego, lecz również orzecznictwo sądów powszechnych oraz osiągnięcia nauki postępowania karnego i cywilnego. Konstrukcja dowodu z opinii biegłego jest w procedurach sądowych oraz administracyjnej zbliżona, w związku 
z tym przy rozstrzyganiu problemów wynikłych na tle postępowania administracyjnego za dopuszczalne, a niekiedy nawet konieczne, uznać należy sięganie do poglądów przyjętych w doktrynie postępowania cywilnego i karnego. Jest to szczególnie istotne w tych obszarach, w których nie ma szczegółowej regulacji k.p.a., takich właśnie jak konfrontacja biegłych.

Zgodzić należy się z Naczelnym Sądem Administracyjnym, że konfrontacja biegłych powinna zostać przeprowadzona w zaistniałym stanie faktycznym na rozprawie administracyjnej. Zwrócić należy jednocześnie uwagę, że posługując się sformułowaniem „wydaje się", NSA nie nadał swojemu stanowisku charakteru wypowiedzi kategorycznej (podobnie uczynił WSA w Lublinie w przywołanym już wyroku z dnia 23 maja 2017 r.). Ponieważ obowiązek przeprowadzenia rozprawy administracyjnej w sytuacji, w której istnieje potrzeba przesłuchania w sprawie co najmniej dwóch biegłych, nie jest w świetle treści przepisu art. 89 § 2 k.p.a. jednoznaczny, zgodzić należy się z NSA również w kwestii sposobu samego sformułowania poglądu zaprezentowanego w orzeczeniu.

Zgodnie z treścią przepisu art. 89 § 2 k.p.a., organ powinien przeprowadzić rozprawę, gdy zachodzi potrzeba uzgodnienia interesów stron oraz gdy jest to potrzebne do wyjaśnienia sprawy przy udziale świadków lub biegłych albo w drodze oględzin. W doktrynie postępowania administracyjnego nie ma zgody co do tego, czy w przypadku zaistnienia potrzeby wykorzystania środków dowodowych wskazanych w art. 89 § 2 k.p.a. rozprawa jest obligatoryjną formą prowadzenia postępowania wyjaśniającego. Zgodnie z jednym z poglądów, przyjętym przez Wacława Dawidowicza, w przypadku wyjaśniania sprawy przy udziale świadków lub biegłych albo w drodze oględzin, organ prowadzący postępowanie obowiązany jest zawsze posłużyć się formą rozprawy ${ }^{27}$. W doktrynie pogląd ten poddany został krytyce. Zbigniew Janowicz ${ }^{28}$ oraz Andrzej Wróbel ${ }^{29}$ uznali, że wykładnia przepisu art. 89 § 2 k.p.a. nie prowadzi do wniosku, że przeprowadzenie rozprawy jest obligatoryjne w każdym przypadku wyjaśniania sprawy przy udziale świadków lub biegłych albo w drodze oględzin. Wskazani autorzy podzielili pogląd sformułowany przez Emanuela Iserzona, który zwrócił uwagę na dodatkowy warunek przeprowadzenia rozprawy, poza warunkiem udziału świadków, biegłych lub dokonania oględzin - „warunek potrzeby rozprawy”. Jak zaznaczył E. Iserzon, „jeżeli np. należy zbadać dwóch świadków, potrzeba rozprawy - w świetle intencji autorów k.p.a. uzewnętrznionej w całości redakcji art. 82 [obecnie art. 89 k.p.a. - przyp. A.B.] - wydaje się wątpliwa" ${ }^{\prime 30}$. Jak zauważył Grzegorz Łaszczyca, cel, jakim jest wyjaśnienie sprawy przy udziale świadków lub biegłych albo w drodze oględzin, może zostać osiągnięty także w postępowaniu gabinetowym ${ }^{31}$.

\footnotetext{
27 W. Dawidowicz, Postępowanie administracyjne. Zarys wykładu, Warszawa 1983, s. 164.

28 Z. Janowicz, Kodeks postępowania administracyjnego. Komentarz, Warszawa 1999, s. 257.

29 A. Wróbel [w:] idem, M. Jaśkowska, Kodeks postępowania administracyjnego. Komentarz, Warszawa 2016, s. 508.

30 E. Iserzon [w:] idem, J. Starościak, Kodeks postępowania administracyjnego: komentarz, teksty, wzory i formularze, Warszawa 1970, s. 183.

31 G. Łaszczyca, Rozprawa administracyjna w ogólnym postępowaniu administracyjnym, Warszawa 2008, s. 58.
} 
Pogląd, zgodnie z którym przesłuchanie biegłych jest możliwe również poza rozprawą administracyjną, zasługuje na uwzględnienie. Pamiętać przy tym należy jednak o korzyściach, jakie niesie ze sobą rozprawa administracyjna. Jest ona niewątpliwie doskonalszą formą postępowania wyjaśniającego, która sprzyja koncentracji w postępowaniu środków dowodowych. Organ administracji publicznej powinien rozważyć prowadzenie postępowania wyjaśniającego w formie rozprawy, jeżeli korzysta z dowodu ze świadków lub biegłych, albo z dowodu z oględzin, niezależnie od braku obowiązku przeprowadzenia rozprawy. Jak trafnie przyjął E. Iserzon: „Praktyczne względy przemawiają za zaleceniem, by organ w wątpliwych w świetle art. 82 [obecnie art. 89 k.p.a. - przyp. A.B.] wypadkach przeprowadził rozprawę wobec jej wyższości nad »kameralną" postacią postępowania dowodowego"32.

Odnosząc zaprezentowane poglądy do stanu faktycznego, w którym wydane zostało komentowane orzeczenie NSA, zaakcentować należy istnienie „potrzeby rozprawy". W sytuacji, gdy konieczne jest jednoczesne przesłuchiwanie ośmiu biegłych w celu wyjaśnienia rozbieżności pomiędzy opiniami, niewątpliwie wyjaśnienie sprawy będzie możliwe przy przeprowadzeniu rozprawy. W przypadku tym bowiem konieczna jest koncentracja środków dowodowych, a umożliwia ją właśnie rozprawa ${ }^{33}$.

Wydaje się, że większego komentarza nie wymaga podkreślenie przez NSA, że przy konfrontacji biegłych należy zapewnić stronom możliwości zadawania biegłym pytań, stosownie do dyspozycji art. 10 w zw. z art. 79 § 1 i 2 k.p.a. Przypomnieć w tym miejscu należy, że ważnym celem konfrontacji jest, co wynika z przywołanego już poglądu G. Kopczyńskigo, umożliwienie stronom kontroli dowodu z opinii biegłych ${ }^{34}$. Ponadto treść przepisów art. 79 § 1 i 2 k.p.a. nie pozostawia wątpliwości co do prawa strony do czynnego udziału w czynności przesłuchania biegłego. Dodatkowo prawo strony do zadawania biegłym pytań wynika pośrednio z przepisu art. 95 § 2 k.p.a. ${ }^{35}$ Uniemożliwienie stronie udziału $w$ istotnych czynnościach postępowania wyjaśniającego należy uznać za wyczerpanie przesłanki wznowienia postępowania administracyjnego, wskazanej w art. 145 § 1 pkt 4 k.p.a. („strona bez własnej winy nie brała udziału w postępowaniu") ${ }^{36}$. Niewątpliwie przeprowadzenie konfrontacji biegłych stanowi istotną czynność postępowania wyjaśniającego.

32 E. Iserzon [w:] idem, J. Starościak, Kodeks postępowania..., s. 183.

33 Przepis art. 89 § 2 k.p.a. powinien znaleźć zastosowanie, jak zaznaczył NSA w wyroku z dnia 22 listopada 2007 r., I OSK 1635/06, LEX nr 417729: „Wtedy, gdy zachodzi potrzeba uzgodnienia interesów stron oraz gdy przeprowadzenie rozprawy jest potrzebne do wyjaśnienia sprawy przy udziale świadków, biegłych albo w drodze oględzin, a zwłaszcza gdy konieczne jest przesłuchanie więcej niż jednego świadka, kilku biegłych. Rozprawa zapewnia bowiem możliwość ich konfrontacji".

34 G. Kopczyński, Konfrontacja biegłych..., s. 113-114.

35 Przepis art. 95 \& 2 k.p.a. przyznaje kierującemu rozprawą kompetencję do uchylania zadawanych świadkom, biegłym i stronom pytań, jeżeli nie mają one istotnego znaczenia dla sprawy. Na żądanie strony osnowa treści uchylonego pytania powinna zostać zamieszczona w protokole.

36 Zob. W. Dawidowicz, Ogólne postępowanie administracyjne. Zarys systemu, Warszawa 1962, s. 232; B. Adamiak [w:] eadem, J. Borkowski, Kodeks postępowania administracyjnego. Komentarz, Warszawa 2016, s. 661. 
W kontekście stanu faktycznego, w którym zostało wydane komentowane orzeczenie NSA, rozważenia wymaga dopuszczalność przeprowadzenia w postępowaniu administracyjnym tzw. konfrontacji pośredniej, polegającej na skonfrontowaniu zeznań lub wyjaśnień jednej osoby z protokołem przesłuchania innej osoby ${ }^{37}$. W nauce prawa karnego procesowego przeprowadzanie takiej konfrontacji poddane zostało krytyce. Podkreśla się, że w jej miejsce organ powinien dążyć do bezpośredniego przesłuchania biegłych lub spowodowania ich równoczesnego przesłuchania ${ }^{38}$. Wydaje się, że w postępowaniu administracyjnym, w którym obowiązuje zasada pisemności postępowania (art. 14 k.p.a.), a podstawową formą postępowania wyjaśniającego jest postępowanie gabinetowe, prowadzenie konfrontacji pośredniej może być w niektórych sytuacjach uzasadnione. Nie chodzi jednak o takie przypadki, w których istnieje potrzeba jednoczesnego przesłuchania kilku biegłych, a zarazem zachodzi „potrzeba rozprawy" wynikająca z konieczności koncentracji środków dowodowych. Prowadzenie konfrontacji pośredniej należy natomiast dopuścić wówczas, gdy organ dysponuje w sprawie jedną opinią biegłego i dokonuje w toku rozpatrywania tej sprawy czynności przesłuchania innego biegłego. W takiej sytuacji nie ma przeszkód, aby podczas przesłuchania organ zwrócił się do biegłego o ustosunkowanie się do treści opinii, której ten nie jest autorem. Konfrontacja pośrednia może być także prowadzona w przypadku, gdy jednoczesne przesłuchanie biegłych jest z jakiegoś powodu utrudnione lub niemożliwe (np. z powodu uchylania się biegłego, pomimo zastosowania środków przymusu, od udziału w przesłuchaniu lub z powodu jego choroby). Podkreślenia wymaga, że w stanie faktycznym, w którym zapadło komentowane orzeczenie NSA, ze względu na liczbę opinii, którymi dysponowały organy administracji publicznej, jak również potrzebę zapewnienia stronie udziału w postępowaniu dowodowym, organ zobowiązany był do skorzystania z formy konfrontacji bezpośredniej, czyli jednoczesnego przesłuchania autorów sprzecznych ze sobą opinii. Zwrócić należy jednak uwagę, że w analizowanej sprawie, pomimo wezwania na rozprawę wszystkich biegłych, dwóch z nich nie stawiło się na wezwanie. Z uzasadnienia komentowanego orzeczenia NSA wynika, że do tych biegłych, którzy byli obecni na rozprawie, zwrócono się o ustosunkowanie się do opinii jednego z nieobecnych biegłych. Zatem organ prowadzący postępowanie skorzystał również w pewnym zakresie z formy konfrontacji pośredniej. Ponadto, do nieobecnego biegłego, na jego wniosek, organ skierował na piśmie pytania, które dotyczyły również oceny innych opinii39. Takie działania organu uznać należy za prawidłowe, ponieważ nie miały one na celu uniknięcia bezpośredniej konfrontacji biegłych, lecz umożliwienie - w przypadku gdy bezpośrednie skonfrontowanie wszystkich biegłych było niemożliwe - kompleksowej oceny wydanych w sprawie opinii, a tym samym prawidłowego wyjaśnienia stanu faktycznego sprawy.

37 J. Widacki [w:] Kryminalistyka, red. idem, Warszawa 2008, s. 142.

38 G. Kopczyński, Konfrontacja biegłych..., s. 107.

39 Ostatecznie, jak wynika z uzasadnienia glosowanego wyroku NSA, biegły w swojej pisemnej odpowiedzi na pytania organu stwierdził, że „ocena innych opinii może zostać przezeń przeprowadzona na podstawie dodatkowego zlecenia za stosownym wynagrodzeniem". 
Reasumując rozważania podjęte w glosie, po pierwsze, podkreślić należy trafność przyjętej przez NSA tezy - co do samej potrzeby przeprowadzenia konfrontacji biegłych, gdy ich opinie mają diametralnie różne konkluzje, co do rozprawy jako właściwej formy przeprowadzenia konfrontacji, jak również co do konieczności respektowania uprawnień procesowych strony. Po drugie, docenić należy orzeczenie NSA z tego powodu, że jest ono doskonałym przykładem na to, jak orzecznictwo sądów administracyjnych kompensować może pewne mankamenty wynikające z lapidarności przepisów kodeksu postępowania administracyjnego.

\section{Literatura}

Adamiak B., Borkowski J., Kodeks postępowania administracyjnego. Komentarz, Warszawa 2016. Cora Ł., Charakter prawny czynności kontrolujących dowody ",Przegląd Sądowy” 2018, nr 11-12. Dawidowicz W., Ogólne postępowanie administracyjne. Zarys systemu, Warszawa 1962.

Dawidowicz W., Postępowanie administracyjne. Zarys wykładu, Warszawa 1983.

Gurgul J., Glosa do postanowienia SN z dnia 27 lutego 2001 r., III KKN 484/99, „Prokuratura i Prawo” 2002, $\mathrm{nr} 2$.

Iserzon E., Starościak J., Kodeks postępowania administracyjnego: komentarz, teksty, wzory i formularze, Warszawa 1970.

Jagiełło D., Glosa do wyroku s.apel. z dnia 3 października 2012 r., Il AKa 260/12, „lus Novum” 2013, $\mathrm{nr} 4$.

Janowicz Z., Kodeks postępowania administracyjnego. Komentarz, Warszawa 1999.

Jaśkowska M., Wróbel A., Kodeks postępowania administracyjnego. Komentarz, Warszawa 2016.

Kodeks postępowania administracyjnego. Komentarz, red. R. Hauser, M. Wierzbowski, Warszawa 2018.

Kodeks postępowania karnego, t. 1, Komentarz do art. 1-424, red. L.K. Paprzycki, Warszawa 2013. Kopczyński G., Konfrontacja biegłych w polskim procesie karnym, Warszawa 2008.

Kryminalistyka, red. J. Widacki, Warszawa 2008.

Łaszczyca G., Rozprawa administracyjna w ogólnym postępowaniu administracyjnym, Warszawa 2008.

Orkiszewska D., Glosa do postanowienia SN z dnia 20 sierpnia 2014 r., II KK 204/14, „Prokuratura i Prawo" 2016, nr 2.

Tomaszewski T., Dowód z opinii biegłego w procesie karnym, Kraków 2000.

Żylińska J., Konfrontacja biegłych jako metoda wyjaśnienia sprzeczności między różnymi opiniami w tej samej sprawie ,"Państwo i Prawo” 2013, z. 10.

Żylińska J., Przesłanki konfrontacji, „Prokuratura i Prawo” 2013, nr 2. 


\section{Streszczenie}

\section{Adam Bochentyn}

\section{Obowiązek przeprowadzenia przez organ administracji publicznej konfrontacji biegłych w przypadku istotnych rozbieżności pomiędzy ich opiniami}

W komentowanym wyroku z dnia 17 października 2019 r., II OSK 1217/19, Naczelny Sąd Administracyjny odniósł się do konfrontacji biegłych, którzy w tej samej sprawie wydali opinie o diametralnie różnych konkluzjach. W ocenie sądu, w przypadku uzyskania takich opinii, obowiązkiem organu jest przeprowadzenie konfrontacji biegłych, podczas której stronie należy zapewnić możliwość zadawania biegłym pytań. Konfrontacja powinna zostać przeprowadzona na rozprawie. Autor glosy, podzielając pogląd przedstawiony przez NSA, przytacza argumenty potwierdzające jego trafność. Akcentuje również znaczenie komentowanego orzeczenia ze względu na brak regulacji k.p.a. w zakresie konfrontacji biegłych.

\section{Summary}

\section{Adam Bochentyn}

Obligation of the public authority to confront experts in the case of significant differences between their opinions

In the commented judgment of 17 October 2019, II OSK 1217/19, the Supreme Administrative Court referred to the confrontation between experts who, in the same case, delivered opinions with diametrically different conclusions. According to the Court, in the case of obtaining such opinions, the authority is obliged to confront the experts and provide the party with the opportunity to ask them questions during the confrontation. The confrontation should be held at the administrative hearing. The author, sharing the opinion expressed by the Supreme Administrative Court, presents arguments confirming its accuracy. He also emphasizes the importance of the commented judgment because of the lack of regulation in the Code of Administrative Procedure regarding the confrontation of experts.

Słowa kluczowe: biegły, konfrontacja biegłych, postępowanie dowodowe, rozprawa administracyjna, udział strony w przesłuchaniu biegłego

Keywords: expert, confrontation of experts, evidentiary process, administrative hearing, participation of a party in the hearing of an expert 
